\title{
ANTROPOLINGWISTYKA DZISIAJ: WYNIKI I PERSPEKTYWY
}

\author{
JAN ZANIEWSKI, \\ SERGIUSZ GRINIEV-GRINIEWICZ, \\ NATALLIA NIZHNEVA
}

\section{Narodziny antropolingwistyki, jako nauki}

Antropolingwistyka (lingwistyka antropologiczna) jest dyscypliną naukową, zajmującą się badaniem ewolucji myślenia, rozwoju ludzkiego rozumowania z punktu widzenia odzwierciedlenia tego procesu w języku, a w szczególności w słownictwie, ponieważ wszystkie historyczne zmiany w świadomości ludzkiej, rozwoju kultury i wzroście wiedzy mają odbicie w systemie leksykalnym języka. W słowie zawarte są najróżniejsze dane lingwistyczne: fonetyczne, morfologiczne, leksykograficzne, syntaktyczne, socjo- i etnograficzne, nie mówiąc już o elementach logiki, psychologii, filozofii ${ }^{1}$. Niektórzy językoznawcy wyróżniają w słowie nawet kilkadziesiąt parametrów leksykograficznych, np. Jurij Karaułow naliczył ich $68^{2}$.

Pojawienie się antropolingwistyki było ogłoszone na Międzynarodowej Konferencji „Język $i$ kultura”, zorganizowanej przez Wydział Filologii Angielskiej Wyższej Szkoły Finansów i Zarządzania w Białymstoku w czerwcu 2004 r. Podczas tej konferencji czołowi uczeni Białorusi, Danii, Niemiec, Polski, Rosji, Ukrainy, Wielkiej Brytanii, pracujący w dziedzinie leksykologii i terminoznawstwa, lingwistyki kognitywnej i językoznawstwa porównawczego podpisali „Manifest Białostocki”,

\footnotetext{
${ }^{1}$ Д. Шмелёв. Проблемы семантического анализа лексики. Наука, Москва 1973.

${ }^{2}$ Ю. Караулов. Лингвистическое конструирование и тезаурус литературного языка. Наука, Москва 1981, 138 с.

${ }^{3}$ S. Griniewicz, J. Zaniewski, T. Skopiuk, E. Sorokina. Antropolingwistyka (nowa nauka XXI wieku). Białystok, WSFiZ, 2009, s.109.
} 
w którym zostały określone przesłanki pojawienia się i podstawowe cechy antropolingwistyki. Specyfiką antropolingwistyki jest koncentracja uwagi na ewolucji myślenia i odbiciu tego procesu w języku, a szczególnie w leksyce (słownictwie), co staje się nadzwyczaj ważnym elementem w związku z niedawnymi odkryciami w antropologii ogólnej i powstającej w wyniku tego konieczności zrewidowania i uściślenia teorii ewolucji.

Twórcami nowej dziedziny lingwistycznej jest międzynarodowy zespół w składzie: prof. Sergiusz Griniew-Griniewicz (UwB), prof. Jan Zaniewski (WSFiZ), prof. Tatiana Skopiuk (Ukraińska Akademia Nauk), prof. Elwira Sorokina (Uniwersytet im. Łomonosowa w Moskwie).

W 2009 roku ukazała pierwsza w Polsce monografia naukowa pt. ANTROPOLINGWISTYKA (nowa nauka XXI wieku) autorstwa twórców tej nauki, a w Rosji istnieje już ponad 10 wydań akademickich tego podręcznika.

Powstanie lingwistyki antropologicznej jako nowej dyscypliny naukowej zostało zarejestrowane w Międzynarodowej Organizacji Ekspertów, znalazło uznanie i jest już ona uprawiana na Zachodzie i Wschodzie Europy jako dyscyplina uniwersytecka (nb. prace magisterskie, rozprawy doktorskie i habilitacyjne) ${ }^{4}$.

Tematyka antropolingwistyki jest ściśle związana $\mathrm{z}$ tradycyjnym zakresem lingwistycznym „Język i myślenie”, który jest jednym z najtrudniejszych, chociaż i ogólnych zakresów, nie tylko w językoznawstwie, lecz i w szeregu nauk humanistycznych, w pierwszej kolejności w filozofii. Trudności te są wywołane tym, że, po pierwsze, dany temat, chociaż zawsze był jednym z podstawowych $\mathrm{w}$ badaniach lingwistycznych, usytuowany jest jakby na granicy dwóch (a w ostatnim czasie znacznie większej liczby) nauk, co wywołuje konieczność użycia pojęć z pokrewnych dziedzin wiedzy. Po drugie, trudności te mogą być wywołane określonym niewyraźnym charakterem pojęć, wyjaśnianych niedostateczną znajomością naszej współczesnej wiedzy o mechanizmie ludzkiego myślenia.

W niniejszej pracy rozwój wiedzy nie jest rozpatrywany na przykładzie takich wymagających specjalistycznego przygotowania nauk jak, na przykład, fizyka czy matematyka, a na bazie rozwoju wyobrażeń, należących do powszechnie przyjętych dziedzin wiedzy, takich jak: pogoda, emocje, choroba, siedlisko, meble, owoce, warzywa - istniejących równolegle z człowiekiem z dawien dawna. Problem nie jest analizowany na przykładzie i tle jakiegoś pojedynczego języka, powiedzmy angielskiego, arabskiego, chińskiego, polskiego czy rosyjskiego, a na podstawie wielu języków i wspólnot narodowych. Dlatego w rozwoju może uczestniczyć wiele narodów, zarówno posiadających pismo lub jeszcze go nie posiadających.

W historii językoznawstwa był już wykorzystywany termin 'antropologia lingwistyczna' związany z osobą Franza Boasa, Eduarda Sapira i Benjamina Lee

\footnotetext{
${ }^{4}$ С. Гринев-Гриневич, В. Гринева, Л. Минкова, Т. Скопюк. Указатель терминологических диссертачий: Справочное пособие. РоссТем. Белосток - Москва, 2006.
} 
Whorfa, którzy badali stosunki pomiędzy językami i narodowymi (etnicznymi) stylami myślenia. Jednak przesłanki antropolingwistyki, które spowodowały pojawienie się tej nowej dyscypliny naukowej, powstały w końcu XX stulecia:

Należałoby w tym kontekście wymienić następujące czynniki:

1) w tym czasie stworzona była metodologia badania pól semantycznych;

2) pojawiło się i rozpowszechniło systemowe podejście w badaniach naukowych;

3) nagromadzono dane z zakresu badań etymologicznych i diachronicznych, zarówno pojedyńczych słów, jak i grup leksykalnych;

4) pojawiło się terminoznawstwo, badające terminologie narodowe, skorelowane z różnymi polami semantycznymi;

5) powstała konieczność opracowania środków lingwistycznych dotyczących modelowania ludzkiego myślenia i poznania w systemach sztucznego intelektu;

6) ostatnie dane w badaniach nad możliwościami nauczania wyższych naczelnych języka znaków pozwoliły zauważyć u tychże naczelnych zdolności do rozumowania, analogiczne do ludzkich;

7) nastąpił znaczny wzrost zainteresowania problemem wykrycia podstawowych zasad myślenia.

Dało to możliwość zauważenia nowych aspektów tego problemu i znalazło odbicie w powiększeniu liczby odpowiednich dyscyplin naukowych - gnoseologii, epistemologii i logiki oraz późniejszym opracowaniu systemów sztucznego intelektu, psychologii rozwojowej, psychologii pedagogicznej, (ponieważ nauczanie jest także procesem poznania), kończąc na takich niedawno powstałych dyscyplinach jak psychologia kognitywna, psychologia narodowa, etnolingwistyka, lingwistyka kognitywna i kulturologia (chociaż $\mathrm{i}$ ten spis nie jest jeszcze pełny).

Jednocześnie należy podkreślić, że w żadnej z wymienionych dyscyplin naukowych praktycznie nie było prób zbadania ewolucji myślenia z punktu widzenia jej odbicia w języku, w szczególności w leksyce. Ten aspekt badań kognitywnych staje się szczególnie ważnym w związku z ostatnimi odkryciami w antropologii ogólnej i pojawiającą się koniecznością uściślenia teorii ewolucji.

W historii kształtowania się jakiejkolwiek dziedziny wiedzy naukowej można wydzielić szereg podstawowych etapów, a przede wszystkim etap przednaukowy i naukowy. Przy badaniu ewolucji najstarszych dziedzin wiedzy wydziela się trzy etapy ich rozwoju - etap przednaukowy, kiedy w myśleniu ludzi korzystano z wyobrażeń i nazw w postaci zwykłych słów, etap protonaukowy (wczesny, prymitywnonaukowy) operujący specjalnymi wyobrażeniami, nazwami, których są proterminami, i szczególnie etap naukowy polegający na operowaniu pojęciami i terminami. Na przykład, badanie historii leksyki 'meteorologicznej' języka angielskiego, polskiego i rosyjskiego pokazuje obecność trzech warstw chronologicznych. Warstwa 'najstarsza', związana z nazwami opadów, rozwinęła się ze słów powszechnie używanych, potocznych (deszcz, śnieg, rosa, grad itd.) i ich angielskich odpowiedni- 
ków, istniejących jeszcze $\mathrm{w}$ języku ogólnosłowiańskim i ogólnogermańskim. Według chronologii, następna warstwa (datowana na XV-XVIII w.) związana jest z nazwami lokalnymi wiatrów (tramontana, fen, surazu, wentania, itd). Słowa te posiadają już określone specjalistyczne cechy; są one zapożyczone z różnych języków i należą do leksyki specjalistycznej. Warstwa trzecia, ukształtowana w XIX$\mathrm{XX}$ wieku, składa się z utworzonych na łacińskiej podstawie terminów - nazw chmur, które od samego początku tworzyły terminy naukowe, oznaczające pojęcia ${ }^{5}$.

\section{Protoludzki okres rozwoju czlowieka}

Porównując główne etapy ewolucji myślenia człowieka i jego języka łatwo jest zauważyć, że najbardziej zbadanym jest współczesny system leksyki specjalistycznej, wówczas, kiedy właściwości najwcześniejszego języka, okresu 'protoludzkiego' mogą być określone jedynie $\mathrm{z}$ dużym prawdopodobieństwem, ponieważ brak jest zachowanych do naszych dni źródeł pisemnych tego okresu (o ile one w ogóle istniały). Okres ten, poprzedzający pojawienie się współczesnego człowieka, rozpoczął się z wyodrębnienia człowieka, jako biologicznego gatunku 6-8 milionów lat wstecz (niektóre ostatnie dane wskazują na $14 \mathrm{mln}$.) i zakończył się pojawieniem współczesnego kromańskiego typu człowieka (homo sapiens). Jak się wydaje, okres ten nie był praktycznie dobrze zbadany z lingwistycznego punktu widzenia, a przy braku tekstów dotyczących tego okresu, obecnie możemy tylko próbować $\mathrm{z}$ pewnym prawdopodobieństwem określić jego podstawowe cechy. Możemy wydzielić tu trzy zagadnienia: 1) W jaki sposób powstał język? 2) Kiedy to się odbyło? 3) Jakie były jego główne cechy?

Najpełniej w językoznawstwie opracowany jest problem pochodzenia języka. Istnieje kilka grup teorii pojawienia się języka, z których najbardziej udokumentowanym wydaje się być następujący bieg tego procesu. Na początku były mimowolne okrzyki, charakteryzujące się dźwiękowym wyrażeniem uczuć ówczesnej istoty (połowa człowieka - połowa małpy) lub jeszcze wzbogacane pobudzającymi gestami, wykorzystywanymi we wspólnych działaniach. Z czasem konieczność koordynacji działań wzrastała i stosowany pierwotny system dźwięków powiększał się, przechodząc stopniowo od pojedyńczych dźwięków do sylab (jako proto-słów).

O czasie pojawienia się języka można powiedzieć, że problem ten znalazł bardziej znaczące odbicie w antropologii, niż w językoznawstwie. W wielu monografiach antropologicznych zawarte są przypuszczenia o przybliżonym okresie powstania języka, w tym czasie, podczas gdy językoznawstwo ogranicza się tylko do referowania istniejących hipotez o możliwych drogach jego pojawienia się. W ostat-

5 Лазарева М.А. 1999. Сопоставительный анализ метеорологической лексики английского и русского языков. Автореферат Дисс. канд. филол. Наук. Москва, 19 с. 
nim okresie w publikacjach naukowych obserwuje się duże wahania w określaniu czasu pojawienia się języka: 1-1,5 mln. lat wstecz do 33-35 tysięcy lat. Na podstawie szeregu przesłanek i wskutek doprecyzowania jeszcze w 1994 roku poglądu, wydaje się, że język pojawił się 250-300 tysięcy lat wstecz.

Odnośnie specyfiki języka okresu protoludzkiego, który praktycznie nie był w odpowiedni sposób badany z punktu widzenia lingwistyki, to przy braku tekstów $\mathrm{z}$ tego okresu, możemy tylko spróbować z pewną dozą prawdopodobieństwa określić jego podstawowe parametry. W tym celu istnieją dwa sposoby: 1) logiczna rekonstrukcja na podstawie znanych nam faktów biologicznych i 2) porównanie z rozwojem mowy dzieci z wczesnego dzieciństwa. Dla późniejszych etapów wykorzystuje się etnograficzne obserwacje plemion znajdujących się na wczesnych etapach rozwoju.

\section{Protonaukowy (przednaukowy) etap rozwoju czlowieka}

Następnym, najmniej zbadanym, $\mathrm{z}$ tych trzech etapów rozwoju leksyki (już uformowanego człowieka) jest okres 'przednaukowy'. Możliwe, że początek tego okresu związany z pojawieniem się człowieka kromaniońskiego (Homo sapiens fossilis), tj. około 90-100 tysięcy lat wstecz. Jednak tylko z pojawieniem się pisma około 5,5 tysiąca lat temu powstaje bardziej określona informacja o leksyce wczesnego człowieka. W tym czasie, jak się przypuszcza, winny były już istnieć najważniejsze nazwy obiektów i zjawisk otaczających człowieka, a także przedmiotów codziennego użytku. Okres ten trwał do średniowiecza, a leksykon był zależny od otaczających warunków i zmieniał się dość wolno.

Prawdopodobnie, w końcu okresu przedpiśmiennego (5,5 tys. lat wstecz) aktywny słownik ówczesnego człowieka liczył 300-400 słów. Wraz z pojawieniem się pisma winna była pojawić się różnica pomiędzy słownikiem aktywnym i pasywnym, a także różnica między objętością słownika człowieka piśmiennego i niepiśmiennego.

Naturalnie, obraz świata człowieka tego okresu znacznie różnił się od naszego, ponieważ żył on w zupełnie innym świecie. Zwykle w takich przypadkach, kiedy spotykamy w starych tekstach znane słowa, wydaje się nam, że dokładnie rozumiemy ich znaczenie, jednak w rzeczywistości podświadomie przydajemy dawnej świadomości współczesne kategorie myślenia. Pozostaje ustalenie, na ile dawne znaczenia pokrywają się ze znaczeniem mowy dziecka. Przeprowadzone w tym kierunku badania na podstawie porównania istniejących słowników mowy dziecka w różnych krajach i ustalenia wspólnego leksykonu dają, jak nam się wydaje, możliwość lepszego zrozumienia obrazu istniejącego kiedyś świata.

Drugim etapem duchowego rozwoju człowieka jest 'etap protonaukowy', będący etapem przejściowym od codziennej wiedzy do etapu kształtowania się nauki i może zatem być uważany jako wstępny lub wczesny etap kształtowania się nauki. 
Może on być umiejscowiony w okresie od VI wieku przed naszą erą do V wieku naszej ery - dla cywilizacji antycznej i XIV-XV wieku - dla Europy. Okres ten można nazwać okresem 'wczesnonaukowym', ponieważ w tym czasie kształtowały się pierwotne podstawy wielu głównych współczesnych nauk, lub też 'prymitywnonaukowym', gdyż wiele ówczesnych wyobrażeń naukowych miało prymitywny (pierwotny) charakter.

Z punktu widzenia badań antropolingwistycznych pozytywnym czynnikiem $\mathrm{z}$ tego okresu jest możliwość oparcia się na istniejących danych o historycznych zmianach semantycznych $w$ obrębie słów niektórych języków. Tak więc jednym z kierunków badań winna być analiza istniejących materiałów i wyników obserwacji dotyczących rozwoju historycznego grup leksykalnych i pól semantycznych wielu języków.

Ważną cechą jest ilościowe tempo wzrostu leksyki, ponieważ właśnie w tym okresie ukształtowało się wiele fragmentów współczesnego obrazu świata. Wyniki naszych badań w ciągu ostatnich 15 lat dowodzą, że tempo rozwoju leksyki specjalistycznej w tym okresie jest imponujące. Na przykład, angielskie nazwy schodów i ich elementów w języku staroangielskim liczyły 5 słów, w XIV-XV wieku doszło do nich jeszcze 8, a w XVI-XVIII wieku ich liczba wzrosła ponad czterokrotnie.

W tym okresie stopniowo kształtuje się warstwa leksyki specjalistycznej, która jest przedstawiona za pomocą prototerminów utworzonych na podstawie zewnętrznych, przypadkowych cech obiektów. Podstawą tworzącej się prototerminologii każdej dziedziny wiedzy jest leksyka potoczna. Prototerminy utworzyły się drogą specjalizacji znaczeń potocznych słów, co świadczy o tym, że specjalne wyobrażenia kształtowały się „na glebie” pojęć ogólnych. Znaczenie takich słów jest specjalistyczne i znane tylko osobom reprezentującym określony zawód.

\section{Współczesny (naukowy) okres rozwoju człowieka}

Najbardziej znany nam jest współczesny 'okres naukowy', dający największe możliwości badań. W tym czasie pojawiają się odpowiednie terminologie, definiują się pojęcia, opracowywane są metody badawcze i stosuje się w badaniach odpowiednią technikę. Tylko na tym etapie mamy do czynienia $\mathrm{z}$ terminami, które posiadają określone znaczenie i są świadomie wybierane lub też konstruowane. Tworzą one system: zwykle są umotywowane, ujednolicone, ezoferyczne, pozbawione synonimów i podlegają standaryzacji. Istnieje również tendencja do wydłużania ich formy, co jest odzwierciedleniem ciągłego uściślania konceptów wyobrażeń i pojęć poprzez dodanie do ich nazw cech, co w rezultacie prowadzi do wzrostu połączeń wyrazowych (w tym ich długości i jakości).

Jednak pod względem struktury i przeznaczenia słownictwo specjalistyczne nie jest jednorodne. Niektóre wyrazy (terminy) są ściśle związane $\mathrm{z}$ daną dziedziną 
wiedzy i odzwierciedlają etapy poznania przyrody. Przeznaczenie zaś drugich polega na nazywaniu przedmiotów. Są to oznaczenia nomenklaturowe (tzw. nomeny). Nie mają one bezpośredniego stosunku do teorii. Ich funkcja jest znacznie ograniczona, tzn. nazywają konkretne obiekty: marki przyrządów, instrumentów, towarów, firmowe znaki, np. Validol (lek), Mercedes (samochód), Nokia (telefon), Canon (kamera), Siemens (nazwa firmy).

Natomiast terminy służą ekspresji myślenia teoretycznego i mają charakter teoretyczny. Charakterystyczną cechą terminów jest ich względna jednoznaczność, systemowość, duża dokładność semantyczna, precyzyjność przy oznaczeniu danego obiektu, skłonność do monosemii, neutralność stylistyczna, zunifikowane użycie terminologii w granicach jednego lub kilku języków. Długość życia terminu, szczególnie naukowego, przy wszelkiej możliwej ewolucji i nawet przy radykalnej zmianie jego znaczenia, jest bardziej długotrwała (terminy są z zasady długowieczne) niż oznaczeń nomenklaturowych.

Ogólna tendencja $\mathrm{w}$ rozwoju nauki to specjalizacja, występująca razem z pojawieniem się nowych dyscyplin naukowych. Według danych zamieszczonych w Encyclopedia Britannica, w XX wieku pojawiło się ponad 2,5 tys. nowych dyscyplin naukowych i ich liczba będzie podwajać się po każdym 25-leciu. Jednocześnie z rozwojem wiedzy, każde pole semantyczne dzieli się na mniejsze części, które $\mathrm{z}$ czasem stają się niezależnymi dziedzinami nauki.

W leksyce specjalistycznej doskonale widoczny jest związek między rozwojem języka oraz materialną historią i duchową kulturą narodu. Według wybitnego logika i filozofa Gottloba Fregego (1848-1925) „... to, co znane jest, jako historia pojęć, w rzeczywistości jest albo historia naszego poznania pojęć, albo historia znaczenia stów". Na przykład, nie posiadając innej informacji, na podstawie tylko jednego zbioru słów zawartych w słowniku sumeryjskim, możemy zbudować wyobrażenie o poziomie rozwoju kultury sumeryjskiej (3 tysiące lat przed naszą erą).

Zmiany, które zachodzą w języku, a szczególnie w jego leksyce, stwarzają możliwość prześledzenia nie tylko rozwoju poszczególnych dziedzin wiedzy i kultury, lecz i rozwoju świadomości. Antropogeneza przedstawia sobą stopniowe wznoszenie się na drabinie świadomości. Dlatego wciąż odkrywamy nowe, coraz głębiej położone obszary umysłu. W ewolucji myślenia człowieka możliwe jest prześledzenie poszczególnych etapów, charakteryzujących się objętością i właściwościami słownictwa. Analogiczne zmiany obserwuje się u człowieka w ontogenezie (rozwoju indywidualnym), co nie tylko potwierdza teorię o paralelizmie filogenezy i ontogenezy, sformułowaną w biologii w postaci prawa biogenetycznego, lecz także daje możliwość rekonstrukcji mentalności człowieka na określonych etapach jego ewolucji.

W rozwoju leksyki prześledzić można określone etapy zmian semantycznych i słowotwórczych. Z punktu widzenia słowotwórstwa w większości tematycznych dziedzin leksyki wydzielić można etapy intensywnego wykorzystania różnych środków językowych. We wczesnym okresie podstawową metodą tworzenia leksyki są 
zmiany semantyczne. Możemy sobie wyobrazić, jak w słowie posiadającym nieokreślone, szerokie (ze współczesnego punktu widzenia) znaczenie, pojedyncze części znaczenia wydzielają się wraz z tworzeniem się samodzielnych słów, np. w oksfordzkim słowniku języka angielskiego (Oxford English Dictionary) znajdują się 72 znaczenia słowa head (głowa). Nowe znaczenia mogą pojawiać się na skutek przenośni metaforycznych i metonimicznych (tj. według podobieństwa i kojarzenia się obiektów). Później wiodącym sposobem tworzenia nowych słów staje się sposób morfologiczny, dla którego charakterystyczne są wariacje formy słowa wyjściowego (sufiksacje, prefiksacje, skrócenia itd.).

Wraz z pojawieniem się produkcji manufakturowej i maszynowej najłatwiejszym sposobem tworzenia nazw różnych gatunków wyrobów staje się tworzenie zestawień. Syntaktyczny sposób tworzenia nazw specjalnych jest najbardziej produktywnym narzędziem uzupełniania słownictwa specjalistycznego. Sposób ten polega na przekształcaniu zwykłych, wolnych połączeń wyrazowych $\mathrm{w}$ trwałe „ekwiwalenty słów”. Skutkiem tego jest przeważająca liczba zestawień w większości współczesnych terminologii. Według Ekateriny Mironowej ${ }^{6}$, w zbiorze angielskiej terminologii związanej z oknami i drzwiami, stosunek ten jest następujący: 69 słów i 381 zestawień (15,3\% i 84,6\% ogólnej liczby 449 terminów). W języku rosyjskim łącznie w leksykalnej grupie „okna” i „drzwi” znajduje się 21 słów i 324 zestawień, czyli 6,1\% i 93,9\% ogólnej liczby jednostek.

Podobną sytuację możemy zaobserwować w medycynie (przede wszystkim medycynie klinicznej), gdzie również dominują zestawienia, np.: atrofia poinfekcyjna w przebiegu kity, choroba kociego pazura, koślawość śródstopia wrodzona, osobowość ekspansywno-paranoiczna, zespót rozwidlenia tętnicy głównej, żoładek klapsydrowaty wrodzony, żóltaczka jąder korowych mózgu itp. ${ }^{7} \mathrm{~W}$ ten sposób zbudowane jest $60-95 \%$ składu terminologii języków europejskich za pomocą form jednosłownych, co świadczy o zdecydowanej przewadze zestawień terminologicznych nad terminami i jest charakterystyczną cechą współczesnej leksyki terminologicznej.

Część powszechnie używanych zestawień skraca się dla wygody poprzez: złączenie kilku wyrazów w jedno słowo (stacja sanitarno-epidemiologiczna - sanepid), utratę jednego słowa (oddział chirurgiczny - chirurgia), przekształcenie w złożonoskrócone słowo (fizyka biologiczna - biofizyka), lub przekształcenie terminu w akronimy (acquired immunodeficency syndrome - zespót nabytego upośledzenia odporności - AIDS, odczyn Bernackiego - OB., tomografia komputerowa - TK, prześwietlenie rentgenowskie - rtg).

Taka kolejność wykorzystywania środków słowotwórczych (początkowo, przeważnie semantycznych, następnie morfologicznych, potem syntaktycznych i na

\footnotetext{
${ }^{6}$ Миронова Е. Проблемы эволючии архитектурной терминологии «Окна и двери». МГОУ, Москва 2002.

${ }^{7}$ Polsko-łacińsko-angielski leksykon diagnoz medycznych, red. J.Zaniewski, Poltext, Warszawa 2005.
} 
koniec morfologiczno-syntaktycznych) odnaleźć można w ewolucji terminologii w szeregu języków europejskich.

W aspekcie semantycznym pierwotne, rozmyte znaczenia najwcześniejszych słów, są poddawane stałej korekcie w wyniku pojawiania się nowych słów. Odbywa się wtedy nowy podział znaczeń. Zapożyczeniom słów z języka ogólnego towarzyszy proces specjalizacji, a użycie słów w charakterze terminów powoduje ustalenie dokładnych granic znaczenia. Wraz z rozwojem świadomości człowieka odbywa się stałe uściślanie znaczeń wykorzystywanych słów, tzn. likwidacja ich nieokreśloności i synkretyzmu.

Obok rozwarstwienia leksyki i wydzielenia się terminów, prototerminów i innych specjalistycznych jednostek leksykalnych, niezrozumiałych dla większości ludzi (laików), język powszechnie używany powoli się zmienia. Jednak zachowuje się w nim wiele słów, które funkcjonowały w okresie starożytności i powstaje iluzja utożsamiania, identyfikacji, chociaż znaczenia tych słów różnią się od znaczeń współczesnych. To wskazuje na to, że na niższych poziomach świadomości w wielu kwestiach jesteśmy podobni do ludzi żyjących wiele wieków temu. Różnica zauważalna jest natomiast na wyższych poziomach rozumowania.

Tak jak rozwarstwienie leksyki z pojawieniem słów wykorzystywanych na wyższych poziomach myślenia nie oznacza zniknięcia bardziej wczesnych słów, tak i poprzednie poziomy świadomości nie zniknęły, a istnieją i w naszych czasach. Część naszych działań w życiu codziennym polega na operowaniu ogólnymi wyobrażeniami, część (np. działania techniczne, tj. praca z komputerem, korzystanie $\mathrm{z}$ urządzeń gospodarstwa domowego, z samochodu etc.) potrzebuje wykorzystania wyobrażeń specjalistycznych. W przypadku profesjonalnych narzędzi i działalności naukowej stosujemy pojęcia. W ciągu ostatnich 200 lat znacznie wzrosła objętość słownika wykształconego człowieka, jednak u większości ludzi rozwój języka kończy się wraz z zakończeniem nauki w szkole, w takim przypadku zwiększanie zasobu słownictwa odbywa się w sposób nieznaczny (Makłakow, 2005: 353).

W trakcie ewolucji świadomości i postępującego wzrostu poziomu wiedzy, w leksyce języka i świadomości człowieka zaobserwować można dwa zupełnie przeciwstawne procesy. $Z$ jednej strony zachodzi oddzielenie leksykonu specjalistycznego od leksykonu powszechnie używanego, a z drugiej zaś strony ma miejsce przeciwstawny mu proces wnikania specjalistycznej leksyki do słownika ogólnego. Już w okresie antycznym astronomia i geometria były dziedzinami wiedzy niezrozumiałymi dla przeciętnego człowieka (Kun, 1977: 23). Jednocześnie wraz z rozpowszechnieniem piśmiennictwa, stopniowym zwiększeniem poziomu wykształcenia oraz pojawieniem się techniki bytowej, wiele specjalistycznych leksemów wchodzi do języka ogólnego. W chwili obecnej ogólnie znane stały się pojęcia matematyki $\mathrm{XV}$ wieku, są one uniwersalnymi pojęciami matematyki. Pojęcia naukowe pochodzące z XVII wieku zaliczamy do pojęć powszechnie znanych (Wartofsky, 1968: 284). 
Dzisiaj mamy do czynienia z tendencją do rozwarstwienia poziomu operacyjnego świadomości. Obok krajów europejskich, gdzie coraz więcej ludzi zdobywa stopnie naukowe, gdzie absolwent uczelni $\mathrm{z}$ dyplomem magistra $\mathrm{w}$ instytucjach badawczych wykonuje prace wymagającą niższych kwalifikacji, istnieją kraje, gdzie znaczna część ludności jest analfabetami. Również w krajach rozwiniętych większość społeczeństwa posiada wykształcenie średnie lub niepełne średnie. Czy ludzie, którzy ograniczają się do wykształcenia podstawowego lub niepełnego średniego, zatrzymują swój rozwój intelektualny? Czy w sposób negatywny działa to na ich samopoczucie? Odpowiedzi na te pytania wymagają czasu.

\section{Prognozy i perspektywy}

Nie możemy dać się zwieść temu, że staliśmy się ludźmi dorosłymi. Generalnie, jako typ jeszcze nie dorośliśmy i tylko uznajemy siebie za dorosłych, posiadamy w najlepszym przypadku niepełne średnie wykształcenie i przejawiamy wiele cech nastolatków - nadmierną emocjonalność, niestabilność w swych zainteresowaniach i nastrojach, a także w moralności. Jako biologiczny typ jesteśmy nastolatkami na etapie fizyczno-psychicznego rozwoju ${ }^{8}$. Przeciętny człowiek, nawet Europejczyk, łatwo poddaje się wpływowi środków masowej informacji, zadowala się 'chlebem i widowiskami', nieudolnie wybiera sobie przywódców, przejawia w stosunku do uczonych źle skrywaną podejrzliwość i wrogość dzikusa do wychowawcy. Pomimo tego dość wysoko wspięliśmy się po drabinie rozwoju świadomości po to, by spojrzeć w przyszłość i postarać się odgadnąć niektóre jej cechy. Już dziś człowiek może żyć 120 lat, a w końcu XXI wieku może nawet dożyć 140 lat. Nieprzypadkowo Żydzi nigdy nie śpiewali jubilatom „Sto lat”, tylko zawsze śpiewają „Dwieście lat!”.

Przede wszystkim oszałamiającym jest tempo przyspieszenia rozwoju świadomości człowieka. Jeżeli na przebycie pierwszego, protoludzkiego etapu potrzebne było 6-8 milionów lat, to na przebycie drugiego, przednaukowego już 100 tysięcy lat, a na trzeci, protonaukowy (nawet $\mathrm{z}$ uwzględnieniem wiedzy antycznej) - niewiele ponad tysiąc lat. Można prognozować, że obecny etap naukowy, trwający już ponad 200 lat, zbliża się ku końcowi, a następny etap będzie miał bardziej gwałtowny charakter i możliwe, że już się rozpoczął.

Niektóre cechy tego postnaukowego etapu ewolucji świadomości już zaczynają się zarysowywać. Najbardziej zauważalny jest wzrost objętości słownictwa, którym musimy się sprawnie posługiwać, a spoglądając na specjalizację zawodów, zauważa się podwyższone wymagania odnośnie pamięci człowieka. Wielki poeta i twórca współczesnego języka rosyjskiego Aleksander Puszkin znał 28 tysięcy słów. Adam

\footnotetext{
${ }^{8}$ Кулагина И. Возвратная психология. Учебное пособие для студентов..., ТЦ Сфера, Москва 2004.
} 
Mickiewicz, wielki poeta polski i twórca współczesnego języka polskiego, użył we wszystkich swych utworach około 24 tysiący słów. Objętość słownika maturzysty lat 50-tych XX wieku wynosiła 10-12 tysięcy słów, uśredniony zasób leksykalny współczesnego humanisty stanowi 50-60 tysięcy słów. Prognozuje się, że do końca tego wieku objętość ta stanowić będzie już 100-150 tysięcy jednostek leksykalnych.

Istniejąca dotąd w krajach europejskich tendencja do uzyskiwania powszechnego średniego wykształcenia zaczyna zamieniać się na tendencję do powszechnego, obowiązkowego wyższego wykształcenia i wzrostu liczby stopni naukowych. Można to rozpatrywać jako swoistą dewaluację wyższego wykształcenia, ale porównanie programów uniwersyteckich XIX wieku i początku XXI wieku świadczy o znacznym wzroście poziomu przekazywanej wiedzy.

Także w leksyce języka naturalnego zachodzą poważne zmiany. Liczba nomenklaturowych specjalistycznych jednostek leksykalnych (nomenów) zaczyna znacznie przewyższać liczbę terminów. Jednym z ważniejszych kierunków badań antropolingwistycznych będzie więc ustalenie pełnego spisu charakterystyk podstawowych etapów ewolucji człowieka i zbadanie możliwych kierunków ich przyszłego rozwoju. Największe trudności sprawia okres protoludzki (6-8 mln. - 90-100 tysięcy lat wstecz) rozwoju człowieka, ponieważ dla tego okresu nie ma dokumentów pisanych. Dlatego istnieje tu możliwość zastosowania następującego podejścia: wykorzystanie danych biologicznych, antropologicznych (fizjologicznych), logicznej konstrukcji badań, wykorzystanie metod psychologicznych i istniejących danych, paleoantropologicznych i lingwistycznych metod badawczych.

Dla okresu naukowego charakterystycznym jest gwałtowny liczbowy wzrost terminologii specjalistycznej z wydzieleniem jej specyfiki. Na tym etapie pojawia się szereg zagadnień, mających społeczny, psychologiczny, filozoficzny, antropologiczny i historyczny charakter. Wymagają one wykorzystania metodologicznego aparatu tych nauk. Istnieje szereg możliwych uzupełniających rezultatów badań $\mathrm{w}$ danej dziedzinie, włączając $\mathrm{w}$ to określenie średniego ogólnego wieku rozwoju umysłowego ludzi w różnych epokach historycznych wraz z doprecyzowaniem motywów i przyczyn ich zachowania się; ustalenie prawdziwego znaczenia i celu starych tekstów; wykrycie ogólnych zasad ludzkiego myślenia; prognozowanie dróg i podstawowych cech dalszej ewolucji człowieka jako gatunku. Możemy dziś dokładnie określić średnią wieku rozwoju umysłowego ludzi w różnych epokach historycznych (wraz z doprecyzowaniem motywów i przyczyn ich zachowania się), ustalić ich obraz świata oraz podać prawdziwe cechy starych tekstów, wykryć ogólne zasady myślenia ludzkiego i prognozować dalszą ewolucję człowieka jako gatunku.

W niniejszej pracy autorzy starali się ustalić chociażby przybliżone tendencje w odniesieniu do określonych historycznych stadiów ewolucji świadomości człowieka i tendencje w rozwoju współczesnych ludzi, jednak zaproponowane tutaj uwagi wymagają dalszego sprawdzenia i doprecyzowania. 
Jednym z najbardziej ważnych wniosków wypływających z wyników już przeprowadzonych badań jest fakt, iż poziom procesu poznania $w$ istotny sposób zależy od poziomu rozwoju leksyki specjalistycznej. Dlatego społeczeństwa i rządy wszystkich krajów winny jasno zrozumieć, że czyniąc wysiłki w celu przyśpieszenia rozwoju swojej leksyki specjalistycznej, tworzą warunki dla swego naukowego, przemysłowego i kulturalnego postępu. Tym niemniej, oczekiwać tego w najbliższej przyszłości nie należy, ponieważ jako prawdziwi „,nastolatkowie”, nawet w korzystnych uwarunkowaniach ciągle jeszcze żyjemy tylko dniem dzisiejszym i źle wyobrażamy sobie dzień jutrzejszy.

\section{Bibliografia}

Baron, N.S. 1992. Growing up with language. How children learn to talk. New York: AddisonWesley.

Beaugrande, R. de i W. Dressler. 1981. Introduction to text linguistics. London: Longman.

Bloom, L., Lifter, K. i J. Broughton. 1985. "The convergence of early cognition and language in the second year of life: Problems in conceptualization and measurement". W zbiorze: Barrett, M. (red.). Single-word speech. New York: John Wiley and Sons. 149-180.

Braine, M.D.S. 1963. "The ontogeny of English phrase structure: the first phase". Language 39. 1-13.

Brooks, R.L. i J.E. Obrzut. 1981. "Brain lateralization: implications for infant stimulation and development". Young Children 36.3. 9-16.

Dębski, J. 2005. Podstawy poznania naukowego. Białystok: Wyższa Szkoła Finansów i Zarządzania.

Encyclopedia Britannica. Supplements. 2004.

Fisiak, J. 2000. An outline history of English. Vol. 1: External history. Poznań: Wydawnictwo Poznańskie.

Fromkin, V. i R. Rodman R. 1993. An introduction to language. Fort Worth: Harcourt Brace Jovanovich College Publishers.

Griniev, S. 1996. "Terminology and nomenclature in Russian". Terminology Science and Research 5. 10-14.

Griniewicz, S. 2004. O wspótczesnym podejściu do lingwistyki antropologicznej. Z cyklu Polszczyzna Mazowsza i Podlasia. Cześś VIII. Łomża: Łomżyńskie Towarzystwo Naukowe im. Wagów.

Griniev, S. i S. Raube. 2003. „Lingwistyka antropologiczna a problem poznania”. Pomosty 2. 13.

Griniewicz, S., Zaniewski J., Skopiuk T. i E. Sorokina. 2009. Antropolingwistyka (nowa nauka XXI wieku). Białystok: WSFiZ.

Heinz, A. 1978. Dzieje językoznawstwa w zarysie. Warszawa: PWN.

Lavrova, A. 2004. "Special languages (LSP) and anthropological linguistics (AL)". W zbiorze: Raube, S, Thomas, P. i S. Griniev-Grinievicz (red.). Language and culture. Establishing foundations for anthropological linguistics. Białystok: Wyższa Szkoła Finansów i Zarządzania. $153-160$.

Leitchik, V. 2004. "Les relations entre culture et language: functions communes". W zbiorze: Raube, S, Thomas, P. i S. Griniev-Grinievicz (red.). Language and culture. Establishing foundations for anthropological linguistics. Białystok: Wyższa Szkoła Finansów i Zarządzania. 283-294.

Nizhneva, N., Zaniewski, J. i N. Nizhneva-Ksenafontava. 2012. Languistic gambit: an introduction to the study of language. Białystok: Wyższa Szkoła Finansów i Zarządzania. 
Nosowicz, J. 2004. “Terminologizacja a szybkość zmian językowych”. W zbiorze: Raube, S, Thomas, P. i S. Griniev-Grinievicz (red.). Language and culture. Establishing foundations for anthropological linguistics. Białystok: Wyższa Szkoła Finansów i Zarządzania. 97-105.

Oxford English Dictionary. 1994. 2nd ed. Oxford: Oxford University Press.

Parker, F. i K. Riley. 2005. Linguistics for non-linguists: a primer with exercises. Boston: Allyn and Bacon.

Picht, H. 2004. "Object - idea - concept". W zbiorze: Raube, S., Thomas, P. i S. Griniev-Grinievicz (red.). Language and culture. Establishing foundations for anthropological linguistics. Białystok: Wyższa Szkoła Finansów i Zarządzania. 113-124.

Polański, K. (red.). 1999. Encyklopedia językoznawstwa ogólnego. Wyd. II. Wrocław: Ossolineum.

Sękowska, E. 2000. „Nurt antropologiczno-kulturowy we współczesnym polskim językoznawstwie". Poradnik Językowy 6. 11-20.

Skopiuk, T. 2004. "Writing and civilization". W zbiorze: Raube, S., Thomas, P. i S. GrinievGrinievicz (red.). Language and culture. Establishing foundations for anthropological linguistics. Białystok: Wyższa Szkoła Finansów i Zarządzania. 125-128.

Slobin, D.I. 1994. "Crosslinguistic aspects of child language acquisition". Sophia Linguistica Working Papers in Linguistics 35.

Sorokina, E. 2004. „Динамика развития взглядов на смысл слова”. W zbiorze: Raube, S., Thomas, P. i S. Griniev-Grinievicz (red.). Language and culture. Establishing foundations for anthropological linguistics. Białystok: Wyższa Szkoła Finansów i Zarządzania. 129-148.

Strelau, J. 2000. Psychologia. Tom I: Podstawy psychologii. Gdańsk: Gdańskie Wydawnictwo Psychologiczne.

Wierzbicka, A. 1999. Języ - umyst - kultura. Warszawa: Wydawnictwo Naukowe PWN.

Wilson, E.O. 1991. „Animal communication”. In: Wang, W.S.-Y. (red.). The emergence of language development and evolution: readings from Scientific American magazine. New York: Freeman. 3-15.

Zaniewski, J. 1996. Język nauki-medycyna. Białystok: Akademia Medyczna w Białymstoku.

Zaniewski, J. (red.). 2005. Leksykon polsko-łacińsko-angielski diagnoz medycznych. Warszawa: POLTEXT.

Авербух, Л.Я. 2004. Общая теория термина, Иваново, 252 с.

Гринев, А.С. 2004. Сопоставительный анализ английской и русской архитектурной терминологии (на материале тематического поля «Теория и история архитектурыл)); Дис. ....канд. филол.наук. М., 155 с.

Гринев, С. 2004, О современном состоянии терминоведения (от комплексной науки $\kappa$ комплексу научных дисииплин) - On the present state of terminology science (from complex science to the complex of sciences) // Научно-техническая терминология. Вып. 1, Москва.

Добреньков, В., Кравченко, Ф. Сочиальная антропология. Учебник. ИНФРА-Ь, Москва.

Караулов, Ю. 1981. Лингвистическое конструирование в тезаурус литературного языка. Наука, Москва.

Краиг, Г. 2002. Психология развития. Питер, Санкт-Петербург.

Лазарева, М.А. 1999. Сопоставительныий анализ метеорологической лексики английского и русского языков. Авторреф. Дисс. .канд. филол. Наук. М., 19 с.

Лингвистический энциклопедический словарь, 1990. Москва, Сов. Энциклопедия, 685 с.

Лосев, А. 1992. Философия имени. Наука, Москва.

Тер-Минасова, С. 2000. Язык и международная коммуникация. Слово, Москва.

Шелов, С. 2003. Термин. Терминологичность. Терминологические определения. СпГУ, Санкт-Петербург.

Юрчик, Л. 1989. Языковое мышление и этапы его развития. Афтореф. Канд. дис. Канд. философ. Наук. БГУ, Минск. 
